\title{
ANGULAR PHOTOGRAMMETRIC ANALYSIS OF FACIAL PROFILE OF IGBOS OF ANAM COMMUNITY OF NIGERIA
}

\author{
Chijioke Okeke, Theodora Omaballa
}

\author{
Department of Anatomy, Nnamdi Azikiwe University, Awka, Nigeria
}

\begin{abstract}
Beauty is most expressed by the face than any other part of the body. The beauty and uniqueness of the face is determined by the sizes and shapes of various parts of the face and various facial angles. The aim of this study was to characterize the angular facial profiles of the Indigenes of Anam, for application in aesthetics. It was a cross sectional study. Sample size was 383 (218 males and 165 females) and age range was between 18 to 40 years. Facial photographs were taken with a digital camera. A computer software was used to measure the following angles: nasofrontal (NF) angle, nasomental (NM) angle, nasofacial (NFa) angle, nasolabial (NL) angle and angle of facial convexity (AFC). Means of the angles were determined and test of significance was done using student $t-$ test. The mean age for the sample was $22.09 \pm 0.46$ years (females) and $23.87 \pm 0.44$ years (males). Females had significantly higher values than males in NF angle (females-134.0 $0^{\circ}$ males- $131.0^{\circ}$ ), NM angle (females$129.0^{\circ}$, males- $127.0^{\circ}$, $\mathrm{NL}$ angle (females-78.9 ${ }^{0}$, males-73.4 $4^{\circ}$ ) and AFC (females-165.0 $0^{\circ}$, males- $163.0^{\circ}$ ). There was no significant sex difference in the value of $\mathrm{NFa}$ angle (females $-40.9^{0}$, males $-40.4^{0}$ ). Some of the facial angular measurements correlated with each other in males and females. This study shows that there was significant sex difference in NF, NM, NL angles and AFC, but not in NFa angle. There was mild correlation between the various facial angles in both sexes.
\end{abstract}

Key words: Angular photogrammetric analysis; Facial profile; Anam; Igbos; Nigeria

\section{RESUMEN}

La belleza es más expresada por la cara que cualquier otra parte del cuerpo. La belleza y singularidad de la cara está determinada por los tamaños y formas de varias partes de la cara y varios ángulos faciales. El objetivo de este estudio fue caracterizar los perfiles faciales angulares de los indigenes de Anam, para su aplicación en la estética. Fue un estudio transversal. El tamaño de la muestra fue de 383 (218 hombres y 165 mujeres) y el rango de edad fue entre 18 y 40 años. Se tomaron fotografías faciales con una cámara digital. Se utilizó un software para medir los siguientes ángulos: ángulo naso-frontal (NF), ángulo naso-mental (NM), ángulo naso-facial (NFa), ángulo naso-labial (NL) y ángulo de convexidad facial (AFC). Se determinaron las medias de los ángulos y se realizó una prueba de significación utilizando la prueba $t$ de Student. La edad media de la muestra fue $22.09 \pm$ 0.46 años (mujeres) y $23.87 \pm 0.44$ años (hombres). Las mujeres tenían valores significativamente más altos que los hombres en ángulo NF (mujeres-134.00, hombres-131.00), ángulo NM (mujeres-129.00, hombres-127.00), ángulo NL (mujeres-78.90, hombres-73.40) y AFC (mujeres-165.00, hombres163.00). No hubo diferencias significativas de sexo en el valor del ángulo NFa (mujeres-40.90, hombres40.40). Algunos de los parámetros angulares faciales se correlacionan entre sí en hombres y mujeres. Este estudio muestra que hubo diferencias sexuales significativas en los ángulos NF, NM, NL y AFC, pero no en el ángulo NFa. Hubo una leve correlación entre los diversos ángulos faciales en ambos sexos.

Palabras clave: Análisis fotogramétrico angular; Perfil facial; Anam; Igbos; Nigeria

\section{INTRODUCTION}

The face is the custodian of physical attractiveness of an individual (Ajami et al, 2015; Akter and Hossain, 2007). It is also the most variable part of the human body. (Ferdousi et al, 2013; Devi et al, 2016).

* Correspondence to: Chijioke M. Okeke.
okeke.chijioke@yahoo.com

Received: 23 January, 2020. Revised: 12 February, 2020. Accepted: 22 March, 2020. 
Physical attractiveness is a strong determinant of self esteem, social acceptance and psychological well being of individuals (Reddy et al, 2011; Devi et al, 2016; Ukoha et al, 2017). The beautifulness of the face is determined by different sizes and shapes of individual parts of the face and the facial angles (Ferdousi et al, 2013). However, perception of beauty also depends on by ethnicity, culture, personality, gender and age. (Akter and Hossain, 2007; Reddy et al, 2011).

Photogrammetry is the study of the facial profile using photograph. Other methods of studying facial soft tissues include radiographic cephalometrics (Mclntyre and Mossey, 2003; Devi et al, 2016), stereophotogrammetry (Sforza and Ferrario, 2006; Wen et al, 2015), computed tomography and laser scanning (Al-Khatib, 2010). Photogrammetric evaluation is non invasive, easy to work with, and provides better evaluation of the harmonic relationships (Devi et al, 2016). The method is less inconvenient to both the examiner and participants and equally saves time (Akter and Hossain, 2007; Ferdousi et al, 2013). The measurements are not affected by tissue sensitivity and compressibility (Wen et al, 2015). These qualities give photogrammetry an edge over other anthropometric methods. Thus, it is the ideal for establishing a population norm (Wen et al, 2015).

Photogrammetry is useful in the field orthodontic surgery, prosthodontic surgery, plastic and reconstructive surgery, maxillofacial surgery, (Reddy et al, 2011), anatomy, physical anthropologists, genetic study, forensic science, aesthetics (Ferdousi et al, 2013), sociology and psychology (Filipović et al, 2019). One of the major goals of orthodontic treatment nowadays is to preserve optimal facial attractiveness (Cindi et al, 2014; Pandian et al, 2018). This is a major addition to the traditional goal of maintaining proper alignment of dentition. Therefore, the clinician needs photographic record of patients for proper treatment and follow up.

Variability in population, as regards genetics and geography makes it inappropriate to use a single standard of craniofacial profile for every group. Therefore, it is necessary to establish a norm for every locality for use in treatment. In Nigeria, facial profile has been reported for Urhobos (Oghenemavwe et al, 2010), Itsekiris (Anibor et al, 2013) and Igalas (Ukoha et al, 2017). This study aims to establish the norm for indigenous members of Anam in Nigeria.

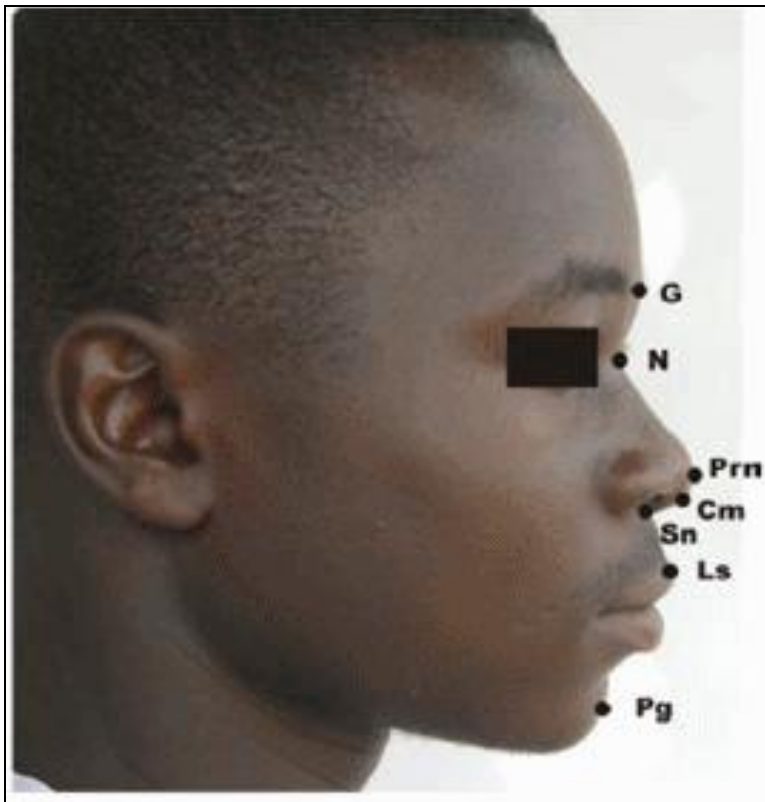

Facial Landmarks: G-Glagella; N-nasion

\section{Prn-Pronasale; Cm-columella: Sn-subnasale}

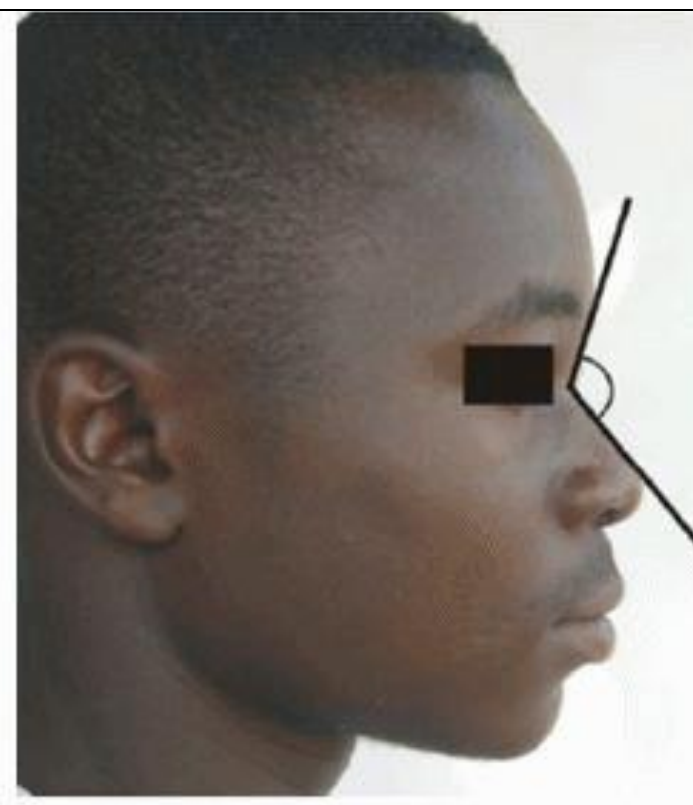

Nasofrontal angle (G-N-Prn)

\section{Ls-labial superior; Pg-pogonion}

Figure 1: Landmarks for measuring facial measurements (adapted from Ukoha et al, 2017) 


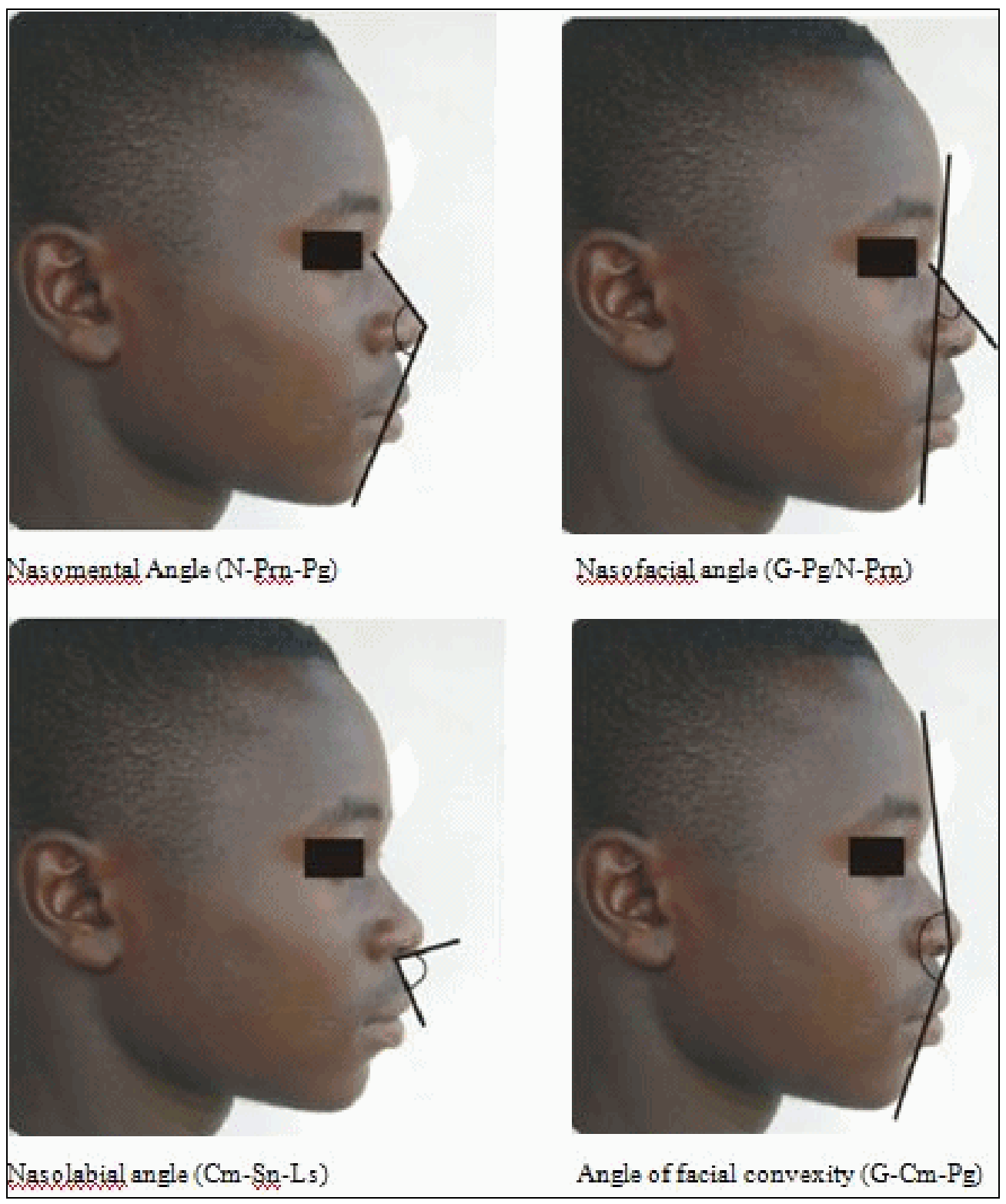

Figure 2: Angular Facial measurements of study (adapted from Ukoha et al, 2017)

\section{MATERIALS AND METHODS}

It was cross sectional study. A total of 383 subjects (218 males and 165 females) within the age range of 18 to 40 years were studied. The mean age for males and females were 23.9 $( \pm 0.44)$ years and $22.1( \pm 0.46)$ years respectively; 36 out of 218 males and 22 out of 165 females were aged 30 years and above. The subjects were free of any congenital or acquired craniofacial abnormalities. The subjects were all from Igbo ethnic group. The parents and grandparents of the subjects were Igbos from Anam community. Ethical approval was obtained from the Ethics Committee of the Faculty of Basic Medical Sciences of our Institution.
Sample size (n) was calculated from the equation: $n=z^{2} p(1-p) / d^{2}$ (Charan and Biswas, 2013) where:

$\mathrm{n}=$ sample size when population is greater than 10,000

$\mathrm{z}$ = standard normal deviate, which corresponds to $95 \%$ confidence level. The value is 1.96

$\mathrm{p}=$ the proportion in the target population. The value is 0.5

$\mathrm{d}=$ degree of accuracy desired. The value is 0.05 Thus $\mathrm{n}=\left(1.96^{2}\right)(0.5)(1-0.5) / 0.05^{2}=384$

Photographs were taken with a Nikon Cool pix (P7700) camera. The camera was held in place with a tripod at a distance of 1.5 meter from the subjects and at the ear level. The study adopted the photographic set up reported by Devi et al 
(2016). The photographs were taken while subjects were standing in a relaxed position with their heads held in the natural head position (NHP).

The photographs were analysed with the use of computer software (Photoshop CS4). The reference points for facial measurements included the following (Figure 1):

Glabella $(\mathrm{G})$ : the most anterior point on the midline of the forehead

Nasion ( $\mathrm{N})$ : the deepest point in the midline of the frontonasal curve

Pronasale (Prn): the most prominent point on the apex of the nose

Columella $(\mathrm{Cm})$ : the most inferior and anterior point on the apex of the nose

Subnasale (Sn): the deepest point in the nasolabial curvature

Labial superior (Ls): the upper lip vermillion border

Pogonion $(\mathrm{Pg})$ : the most anterior point of the chin.

The following angles were measured with the computer software: nasofrontal angle (NF) (Figure 1), nasomental angle (NM), nasofacial angle (NFa), nasolabial angle (NL), and angle of facial convexity (AFC) (figure 2). Two measurements were taken for each of the angles and the mean was calculated.

Method error was calculated with the Dahlberg formula, $D=\sqrt{ }\left(\sum d^{2} / 2 N\right)$ (Galvão et al, 2012), where $d$ is the difference between two measurements, and $\mathrm{N}$ is the total sample size. The method error as calculated for the measurements was as follows: NF $\left(0.5^{0}\right)$, NM $\left(0.4^{0}\right)$, NFa $\left(0.4^{0}\right), \mathrm{NL}\left(0.4^{0}\right)$ and AFC $\left(0.3^{0}\right)$. Index of sexual dimorphism is calculated as follows: [(female mean - male mean)/female mean] $\times 100$.

Pearson correlation was calculated with the Statistical Package for Social Sciences (SPSSversion 21.0). Formula for Pearson correlation ( $r$ ) is given by $n\left(\sum x y\right)-\left(\sum x\right)\left(\sum y\right)$ divided by $\sqrt{\left[n \sum x^{2}-\right.}$ $\left.\left(\sum x\right)^{2}\right]\left[n \sum y^{2}-\left(\sum y\right)^{2}\right]$; where $n=$ sample size, $x$ and $y$ are means of measurements in males and females respectively.

Data was analysed with SPSS (version 21.0). Normality test was done with Shapiro-Wilk separately for each measurement in male and female groups. It was found that the variables were normally distributed in both groups. Descriptive statistics of the angles were obtained separately in males and females, and compared by Student's $t-$ test. The Alpha level $=5 \%$, with a $P$ value of 0.05 . The effect size was calculated by standardized mean difference (Cohen's d index), by the formula $d=\left(M_{1}-M_{2}\right) / S D_{\text {pooled, }}$ (Kotrlik et al, 2011); where $M_{1}$ and $M_{2}$ are the means of the male and female groups, while $\mathrm{SD}_{\text {pooled }}$ is the pooled standard deviation in the two groups. $\mathrm{SD}_{\text {pooled }}=\sqrt{ }\left(\mathrm{SD}_{1}{ }^{2}+\mathrm{SD}_{2}{ }^{2}\right) / 2$.

\begin{tabular}{|c|c|c|c|c|c|c|}
\hline Measurement & Sex & Mean \pm SD & $\mathrm{t}$-value & p-value & Effect size & $\begin{array}{c}\text { Index of sexual } \\
\text { dimorphism }\end{array}$ \\
\hline $\begin{array}{l}\text { Nasofrontal } \\
\text { angle }\left({ }^{0}\right)\end{array}$ & $\begin{array}{c}\text { Female } \\
\text { Male }\end{array}$ & $\begin{array}{l}134.0 \pm 5.7 \\
131.0 \pm 7.1\end{array}$ & 5.112 & $<0.001$ & 0.46 & 2.24 \\
\hline $\begin{array}{l}\text { Nasomental } \\
\text { angle }\left({ }^{0}\right)\end{array}$ & $\begin{array}{c}\text { Female } \\
\text { Male }\end{array}$ & $\begin{array}{l}129.0 \pm 5.1 \\
127.0 \pm 4.4\end{array}$ & 2.980 & 0.003 & 0.42 & 1.55 \\
\hline $\begin{array}{c}\text { Nasofacial angle } \\
\qquad\left({ }^{0}\right)\end{array}$ & $\begin{array}{c}\text { Female } \\
\text { Male }\end{array}$ & $\begin{array}{l}40.9 \pm 4.5 \\
40.4 \pm 4.0\end{array}$ & 0.945 & 0.345 & 0.12 & 1.22 \\
\hline $\begin{array}{c}\text { Nasolabial angle } \\
\qquad\left({ }^{0}\right)\end{array}$ & $\begin{array}{c}\text { Female } \\
\text { Male }\end{array}$ & $\begin{array}{l}78.9 \pm 12.7 \\
73.4 \pm 11.3\end{array}$ & 4.181 & $<0.001$ & 0.46 & 6.97 \\
\hline $\begin{array}{l}\text { Angle of facial } \\
\text { convexity }\left({ }^{0}\right)\end{array}$ & $\begin{array}{c}\text { Female } \\
\text { Male }\end{array}$ & $\begin{array}{l}165.0 \pm 5.7 \\
163.0 \pm 5.2\end{array}$ & 3.205 & 0.001 & 0.37 & 1.21 \\
\hline
\end{tabular}

Table 1: Group Statistics of Craniofacial Angles 


\section{RESULTS}

The mean age in years for males and females were $23.87 \pm 0.44$ and $22.09 \pm 0.46$ respectively. Furthermore, the mean body mass index (BMI) in $\mathrm{kg} / \mathrm{m}^{2}$ for males and females were $21.90 \pm 0.26$ and $21.84 \pm 0.32$ respectively.

The group statistics of the craniofacial angles for males and females are shown in table 1. The mean values of the measurements were higher in females than in males in all the 5 facial measurements. The differences were significant $(p<0.05)$ in 4 of the measurements: nasofrontal angle (NF), nasomental angle (NM), nasolabial angle (NL), and angle of facial convexity (AFC). However, the difference was not significant in nasofacial angle (NFa). The effect size and the index of sexual dimorphism are also shown in
Table 1. NL angle has the highest index of sexual dimorphism (6.97), and is followed by NF angle (2.24).

Table 2 shows correlation of various facial measurements. In females, NM angle has mild significant positive correlation with NF angle, whereas NFa angle has mild significant negative correlation with NF angle and NM angle. AFC has mild negative correlation with $\mathrm{NL}$ angle and a positive correlation with $\mathrm{NM}$ angle. In males, NFa angle has negative and positive correlation with $\mathrm{NF}$ and NM angles respectively. AFC has correlation with all other measurements. The correlation was positive for NM angle and negative for NF, NFa and NL angles.

Table 3 shows comparism of the facial measurements in the present study with the measurements from other studies.

\begin{tabular}{|c|c|c|c|c|c|}
\hline & $\mathrm{NF}$ & NM & $\mathrm{NFa}$ & NL & $\mathrm{AFC}$ \\
\hline Nasofrontal & & $0.196 *$ & $-0.551 *$ & 0.081 & -0.116 \\
\hline angle (NF) & & 0.011 & 0.000 & 0.303 & 0.136 \\
\hline Nasomental & 0.103 & & $-0.298^{*}$ & 0.074 & $0.556^{*}$ \\
\hline (NM) & 0.189 & & 0.000 & 0.343 & 0.000 \\
\hline Nasofacial & $-0.467^{*}$ & $0.469^{*}$ & & -0.109 & 0.037 \\
\hline angle $(\mathrm{NFa})$ & 0.000 & 0.000 & & 0.162 & 0.635 \\
\hline Nasolabial & 0.115 & -0.082 & 0.130 & & $-0.178 *$ \\
\hline angle (NL) & 0.141 & 0.297 & 0.096 & & 0.022 \\
\hline Angle of facial & $-0.284 *$ & $0.531 *$ & $-0.159 *$ & $-0.292 *$ & \\
\hline $\begin{array}{c}\text { convexity } \\
\text { (AFC) }\end{array}$ & 0.000 & 0.000 & 0.042 & 0.000 & \\
\hline
\end{tabular}

Table 2: Correlation of facial angles in males and females. ${ }^{*}=$ significant correlation. Left lower - males. Right upper females

\section{DISCUSSION}

Measurements of craniofacial measurements are important in human identification, gender differentiation and diagnosis of craniofacial abnormality. (Ferdousi et al, 2013). It is also an essential tool in the study of human growth. This is because facial proportions do change with age (Filipović et al, 2019).

Photogrammetric study of the face has advantage over other craniofacial metric studies because it is non invasive, cheap, easy to carry out and it is not affected by soft tissue compressibility on bones. (Wen et al, 2015). Giving the fact that angular photogrammetric images are not affected by enlargement or reduction of the photographic images (Ukoha et al, 2017) and that it provides a permanent record of the appearance of the subject, it is most suited for pre- and post surgical evaluation of patients. 


\begin{tabular}{|c|c|c|c|c|c|c|}
\hline Author/date & Population & $\mathrm{NF}\left({ }^{0}\right)$ & $\mathrm{NM}\left({ }^{0}\right)$ & $\operatorname{NFA}\left({ }^{0}\right)$ & $\mathrm{NL}\left({ }^{0}\right)$ & $\operatorname{AFC}\left({ }^{0}\right)$ \\
\hline Present study & $\begin{array}{l}\text { Anam, } \\
\text { Nigeria }\end{array}$ & $\begin{array}{l}134.0 \quad \pm \\
0.45(\mathrm{~F}) * \\
131.0 \\
0.55(\mathrm{M})\end{array}$ & $\begin{array}{l}129.0 \quad \pm \\
0.40(\mathrm{~F}) * \\
127.0 \quad \pm \\
0.36(\mathrm{M})\end{array}$ & $\begin{array}{ll}40.9 \quad \pm \\
0.35(\mathrm{~F}) \\
40.4 \quad \pm \\
0.31(\mathrm{M}) & \end{array}$ & $\begin{array}{ll}78.9 & \pm \\
0.99(\mathrm{~F}) * & \\
73.4 & \pm \\
0.88(\mathrm{M}) & \end{array}$ & $\begin{array}{l}165.0 \quad \pm \\
0.44(\mathrm{~F}) * \\
163.0 \pm \\
0.39(\mathrm{M})\end{array}$ \\
\hline \multirow{5}{*}{$\begin{array}{l}\text { Park et al } \\
(2018)\end{array}$} & Korea & & & & 97.30 & 142.24 \\
\hline & Chinese & & & & 98.09 & 141.50 \\
\hline & Japanese & & & & 96.33 & 145.18 \\
\hline & $\begin{array}{l}\text { Southeast } \\
\text { Asian }\end{array}$ & & & & 96.24 & 144.26 \\
\hline & American & & & & 104.49 & 142.17 \\
\hline $\begin{array}{l}\text { Ukoha et al } \\
(2017)\end{array}$ & Igala & $\begin{array}{l}130.93 \pm 7.3 \\
4(\mathrm{~F}) \quad * \\
127.73 \pm 7.8 \\
2(\mathrm{M})\end{array}$ & $\begin{array}{l}127.41 \pm \\
5.61(\mathrm{~F}) \\
125.99 \pm \\
4.83(\mathrm{M})\end{array}$ & & $\begin{array}{l}79.29 \pm \\
11.40(\mathrm{~F}) \\
79.48^{0} \pm \\
11.86(\mathrm{M})\end{array}$ & \\
\hline $\begin{array}{l}\text { Akter et al } \\
(2017)\end{array}$ & Bangladeshi & & $\begin{array}{l}127.29(\mathrm{~F}) \\
127.29(\mathrm{M})\end{array}$ & & & \\
\hline $\begin{array}{l}\text { Devi et al } \\
(2016)\end{array}$ & Bengali & & $\begin{array}{l}130.552(\mathrm{~F}) \\
* \quad 128.502 \\
(\mathrm{M})\end{array}$ & & & \\
\hline $\begin{array}{l}\text { Osunwoke et } \\
\text { al (2014) }\end{array}$ & $\begin{array}{l}\text { Khana, } \\
\text { Nigeria }\end{array}$ & $\begin{array}{l}137.36 \pm \\
6.37(\mathrm{~F}) \\
133.63 \pm \\
8.59(\mathrm{M})\end{array}$ & $\begin{array}{l}130.97 \pm \\
5.68(\mathrm{~F}) \\
128.99 \pm \\
5.52(\mathrm{M})\end{array}$ & & & \\
\hline $\begin{array}{l}\text { Ferdousi et al } \\
\text { (2013) }\end{array}$ & $\begin{array}{l}\text { Bangladeshi } \\
\text { Garo }\end{array}$ & $\begin{array}{ll}137.96 & \pm \\
4.79\left(\mathrm{~F}^{*}\right. & \\
129.56 & \pm \\
7.96(\mathrm{M}) & \\
\end{array}$ & $\begin{array}{l}132.79 \pm \\
5.10(\mathrm{~F}) \\
129.75 \pm \\
7.32(\mathrm{M})\end{array}$ & $\begin{array}{l}38.67 \pm \\
4.05(\mathrm{~F}) \\
40.27 \pm \\
4.54(\mathrm{M})\end{array}$ & $\begin{array}{l}91.92 \pm \\
8.90(\mathrm{~F}) \\
91.28 \pm \\
12.98(\mathrm{M})\end{array}$ & \\
\hline $\begin{array}{l}\text { Wamalwa et } \\
\text { al (2011) }\end{array}$ & Kenya & $\begin{array}{l}137.97 \pm \\
5.21(\mathrm{~F}) \\
132.44 \pm \\
6.91(\mathrm{M})\end{array}$ & & & & \\
\hline $\begin{array}{l}\text { Reddy et al } \\
(2011)\end{array}$ & North India & $\begin{array}{l}144.33 \pm \\
1.75(\mathrm{~F}) \\
136.71 \pm \\
3.64(\mathrm{M})\end{array}$ & & $\begin{array}{l}33.69 \pm \\
1.37(\mathrm{~F}) \\
34.38 \pm \\
1.77(\mathrm{M})\end{array}$ & $\begin{array}{l}101.50 \pm \\
4.39(\mathrm{~F}) \\
102.32 \pm \\
4.69(\mathrm{M}\end{array}$ & \\
\hline $\begin{array}{l}\text { Oghenem- } \\
\text { avwe et al } \\
(2010)\end{array}$ & $\begin{array}{l}\text { Urhobos, } \\
\text { Nigeria }\end{array}$ & $\begin{array}{l}127.85 \pm \\
8.50(\mathrm{~F}) \\
121.75 \pm \\
9.07(\mathrm{M})\end{array}$ & & & & \\
\hline $\begin{array}{l}\text { Malkoç et al } \\
\text { (2009) }\end{array}$ & Turkey & $\begin{array}{l}148.61 \pm \\
6.66(\mathrm{~F}) \\
146.03 \pm \\
8.19(\mathrm{M})\end{array}$ & & & $\begin{array}{l}102.94 \pm \\
10.43(\mathrm{~F}) \\
101.09 \pm \\
10.19(\mathrm{M}\end{array}$ & \\
\hline $\begin{array}{l}\text { Anic- } \\
\text { Milosevic et } \\
\text { al (2008) }\end{array}$ & Croatian & $\begin{array}{l}139.11 \pm \\
6.35(\mathrm{~F}) * \\
136.38 \pm \\
6.71(\mathrm{M})\end{array}$ & & $\begin{array}{l}30.36 \pm \\
2.38(\mathrm{~F}) \\
29.53 \pm \\
2.51(\mathrm{M})\end{array}$ & $\begin{array}{l}109.39 \pm \\
7.84(\mathrm{~F}) \\
105.42 \pm \\
9.52(\mathrm{M})\end{array}$ & \\
\hline $\begin{array}{l}\text { Fernandez- } \\
\text { Riveiro et al } \\
(2003)\end{array}$ & Spanish & $\begin{array}{l}141.98 \pm \\
6.06(\mathrm{~F}) * \\
138.57 \pm \\
6.81(\mathrm{M})\end{array}$ & & & $\begin{array}{l}107.57 \pm \\
8.5(\mathrm{~F}) \\
105.20 \pm \\
13.28(\mathrm{M}\end{array}$ & \\
\hline
\end{tabular}

Table 3 - comparative data on angular facial measurements in different population. NF-nasofacial angle, NM-nasomental angle, NFA-nasofrontal angle, NL-nasolabial angle, AFC-angle of facial convexity, Ffemale, M-male. * Denotes significant female-male difference

The findings of our study showed that Anam Nigerian females have larger soft tissue profile facial angles than males. The difference in the mean values of measurements among males and females is significant for nasofrontal angle, nasomental angle, nasolabial angle and angle of facial convexity (Table 1). It was not significant for nasofacial angle. The significant higher value of nasofacial angle in females than in males in our study was also reported by several other 
studies, as detailed in Table 3 . Malkoç et al (2009) reported statistically insignificant gender difference in the nasofacial angle in Turkish Furthermore, the effect size for the angular measurements, in male and female groups is small for nasofacial angle; it is medium for nasofacial, nasomental, nasolabial angles and angle of facial convexity. The effect size expresses the importance of the difference of the measurements between male and female groups. It is thus useful in the field of aesthetics, plastic and reconstructive surgery and in population study.

In our study, nasomental angle (N-Prn-Pg) showed statistically significant sex difference (Table 1). Previous studies by Ukoha et al (2017), Devi et al (2016), Osunwoke and Onyeriodo et al (2014), and Ferdousi et al (2013) also reported statistically significant sex difference in the nasomental angle (n-Prn-Pg) (Table 3). The above finding may be due to more prominent chin in females than in males. However, Akter and Hossain (2017) did not find any significant sex difference in the nasomental angle.

There was no significant sex difference in the nasofacial angle (G-Pg/N-Prn) in the present study. However, the nasofacial angles in our report were larger than that reported by Ferdousi et al (2013), Reddy et al (2011) and AnicyMilosevicy et al (2008).

In the present study, there was significant sex difference in the nasolabial angle. The nasolabial angle from our study (in Nigeria) was more acute than the nasolabial angle reported by Ferdousi et al (2013) in Bangladeshi, Reddy et al (2011) in North India, Malkoc et al (2009) in Turkey, AnicyMilosevicy et al (2008) in Croatia and FernandezRiveiro et al (2003) in Spain (Table 3). These differences are due to differences in race. However, it is comparable to the findings from Igala community in Nigeria by Ukoha et al (2017). This finding suggests that Africans have more acute nasolabial angle than Caucasians, Europeans and Asians. This is further supported by the report of Park et al (2018) on the nasolabial angles of Koreans, Chinese, Japanese, Southeast Asian and American (Table 3).

Some faces are considered more beautiful than others. Beautifulness of the face is multi factorial including ethnicity, culture and personality. But it is also determined by different shapes and angles of the face. A previous study suggested that Western subjects had a protruding forehead, while Asians had a retruded midface and less chin prominence (Park et al, 2018). Facial convexity plays a crucial role in promoting the harmony between the face and the nose. population. The observed narrower nasofacial angle in males may be as a result of more pronounced glabella in males.

Therefore, this angle is most important in surgical correction of the nose (Rhinoplasty), as it is used to appraise the shape of the nose with respect to the face (Park et al, 2018). The angle of facial convexity (G-Prn-Pg) in the current study was $164.0^{\circ} \pm 5.45$. It was higher than angle of facial convexity reported by Park et al (2018) in Korea, China, Japan, Southeast Asia, and America.

Correlation of the facial measurements in males and females are presented in Table 2. It shows that some of the variables correlate with one another. These correlations among the different measurements may be useful in studying the rate of growth of various parts of the face. Also, in the event of alteration of a part of the face, deriving the angle affected by injury from the normal ones may be useful in reconstructive surgery of the face.

Limitation of study

The study is based on two dimensional data, and may not provide a three dimensional representation of the face. The study focused on the angular measurements of the given population without studying the possible effect of age on those angular measurements.

In conclusion, the present study has been able to provide baseline angular facial profile measurements for the study population which will be useful in the field of surgery, anatomy, anthropology and forensic science. The study showed that there was significant sex difference in all the measurements with the exception of nasolabial angle as well as highlighting ethnic variations in the five facial measurements that were studied. The study was not exhaustive. However, it provided a basis for future studies in the field.

\section{Conflict of Interest \\ None}

\section{Funding}

No external funding

\section{Ethical approval}

It was obtained from the ethical committee of the University.

\section{Informed consent \\ It was obtained from subjects}

\section{Contribution}

CMO: Substantial contribution to conception and design, substantial contribution to acquisition of data, substantial contribution to analysis and 
interpretation of data, drafting the article, critically revising the article for important intellectual content, final approval of the version to be published. TCO: Substantial contribution to conception and design, substantial contribution to acquisition of data, substantial contribution to analysis and interpretation of data, drafting the article

\section{REFERENCES}

Ajami S, Najafi HZ, Mahdavi S. 2015. Angular Photogrammetric Analysis of the Soft Tissue Facial Profile of Iranian Young Adults. Iran J Ortho 10: e4981.

Akter L, Hossain MZ. 2017. Angular photogrammetric soft tissue facial profile analysis of Bangladeshi young adults. APOS Trends orthod 7: 279-86.

Al-Khatib, AR. 2010. Facial three dimensional surface imaging: An overview. Archives of Orofacial Sciences. 1: 1-8.

Anibor E, Okobiah R, Okpara I. 2013. Photometric analysis of the facial angle of the Urhobos in Nigeria. Journal of Medical and Applied Sciences 5: 84-93.

Anicy-Milosevicy S, Lapter-Varga M, Slaj $M$. 2008. Analysis of tissue facial profile by means of angular measurement. Eur J Orthod 30: 13540.

Charan J, Biswas T. 2013. How to Calculate Sample Size for Different Study Designs in Medical Research? Indian J Psychol Med. 35: 121-26.

Cindi SYL, Yanqi Y, Ricky WKW, Urban H, John Lo, Colman M. 2014. Angular photogrammetric analysis of the soft tissue profile in 12-year-old southern Chinese. Head \& Face Medicine 10: 56

Devi LD, Das A, Keisam A. 2016. Evaluation of soft tissue facial profile in asult Bengali population by photogrammetric method with angular measurements. International journal of contemporary medical research 3: 1336-39

Ferdousi MA, Mamun AA, Banu JA, Paul S. 2013. Angular Photogrammetric Analysis of the Facial Profile of the Adult Bangladeshi Garo. Advances in Anthropology. 3:188-92

Fernandez-Riveiro P, Smyth-Chamosa E, Suarez -Quintanilla D, Suarez-Cunqueiro M. 2003. Angular photogrammetric analysis of the soft tissue facial profile. European Journal of Orthodontics 25: 393-99.

Filipović GL, Stojanović NM, Jovanović ID, Randjelović PJ, Ilić IR, Djordjević NS, Radulović NS. 2019. Diferences in Angular Photo- grammetric Soft-Tissue Facial Characteristics among Parents and Their Offspring. Medicina. 55: 197

Galvão MCS, Sato JR, Coelho EC. 2012. Dahlberg formula - a novel approach for its evaluation. Dental Press J Orthod. 17: 115-24.

Kotrlik JW, Atherton JC, Williams HA, Jabor MK. 2011. Reporting and interpreting effect size in quantitative agricultural education research. Journal of Agricultural Education 52: 132-42

Malkoç S, Demir A, Uysal T, Canbuldu N. 2009. Angular photogrammetric analysis of the soft tissue facial profile of Turkish adults. Eur $\mathrm{J}$ Orthod. 31: 174-79.

Mclntyre GT, Mossey PA. 2003. Size and shape measurement in contemporary cephalometrics. European Journal of Orthodontics 25: 231-42.

Oghenemavwe EL, Osunwoke AE, Ordu KS, Omovigho O. 2010. Photometric analysis of soft tissue facial profile of adult Urhobos. Asian J Med Sci 2: 248-524.

Osunwoke EA, Onyeriodo G. 2014. Angular photometric analysis of Khana people in Rivers state, Nigeria. Transfusion Clinique et Biologique. 2: 3.

Pandian KS, Krishnan S, Kumar SA. 2018. Angular photogrammetric analysis of the softtissue facial profile of Indian adults. Indian $\mathrm{J}$ Dent Rez. 29: 137-43.

Park CW, Lee MJ, Jung YI. 2018. Photogrammetric Facial Analysis of Attractive Celebrities Using the Glabella for Planning Rhinoplasty and Analyzing Surgical Outcomes. Arch Aesthetic Plast Surg. 24: 105-10

Reddy M, Ahuja NK, Raghav $P$, Kundu V, Mishra VA. 2011. Computer-assisted angular photogrammetric analysis of the soft tissue facial profile of North Indian adults. The Journal of Indian Orthodontic Society. 3: 119-23.

Sforza C, Ferrario VF. 2006. Soft-tissue facial anthropometry in three dimensions: From anatomical landmarks to digital morphology in research, clinics and forensic anthropology. Journal of Anthropological Sciences. 84: 97124.

Ukoha U, Ekezie J, Okeke CM, Osmond Al. 2017. Angular craniofacial photometric analysis of the facial profile of Igalas in Nigeria. Anthropol Open J. SE: S1-S6.

Wamalwa P, Amisi SK, Chen S. 2011. Angular photogrammetric comparison of the soft-tissue facial profile of Kenyans and Chinese. The Journal of Craniofacial Surgery 3: 1064-72.

Wen YF, Wong HM, Lin R, Yin G, McGrath C. 2015. Inter-Ethnic/Racial Facial Variations: A Systematic Review and Bayesian MetaAnalysis of Photogrammetric Studies. PLoS ONE 10: e0134525. 